Note

\title{
LABORATORY REARING TECHNIQUE OF Mahanarva fimbriolata (Stål) (Hemiptera: Cercopidae)
}

\author{
José Francisco Garcia ${ }^{1}$; Paulo Sérgio Machado Botelho ${ }^{2 *}$; José Roberto Postali Parra ${ }^{3}$ \\ ${ }_{2}^{1}$ USP/ESALQ - Programa de Pós-Graduação em Entomologia Agrícola. \\ ${ }_{3}^{2}$ UFSCar/CCA - Depto. de Biotecnologia Vegetal - C.P. 153 - 13600-970 - Araras, SP - Brasil. \\ ${ }^{3}$ USP/ESALQ - Depto. de Entomologia, Fitopatologia e Zoologia Agrícola - C.P. 09 - 13418-900 - Piracicaba, \\ SP - Brasil. \\ *Corresponding author <pbotelho@cca.ufscar.br>
}

\begin{abstract}
Due to the importance of cercopids as pests in sugarcane and forage grass, researches have been conducted in order to address aspects related to the bioecology and control of these insects. The objective of this study was to develop a rearing technique for Mahanarva fimbriolata (Stål) (Hemiptera: Cercopidae) on sugarcane, in the laboratory $\left(25 \pm 1{ }^{\circ} \mathrm{C} ; 70 \pm 10 \% \mathrm{RH}\right.$; and 14-hour photophase). Adults were isolated in cylindrical cages containing one sugarcane plant, with a moistened cotton disc surrounding the base of the plant as a site for oviposition. Eggs were removed from the cotton disc by washing it in running water over sieves and maintained in Petri dishes on moistened filter paper until the nymphs hatched. The newly hatched nymphs were transferred to sugarcane roots and placed into boxes with lids, to keep a moistened and dark environment favoring their development and maintaining the root system, providing food access to the developing nymphs. This method allowed $M$. fimbriolata to be maintained in laboratory conditions throughout the year, which would certainly foster research on this insect.
\end{abstract}

Keywords: root froghopper, sugarcane

\section{TÉCNICA DE CRIAÇÃO, EM LATORATÓRIO, DE Mahanarva fimbriolata (Stål) (Hemiptera: Cercopidae)}

\begin{abstract}
RESUMO: Devido à importância da cigarrinha como praga da cultura da cana-de-açúcar, diversos estudos tem sido conduzidos para elucidar aspectos relacionados à bioecologia e controle desses insetos. Esta pesquisa foi realizada com o objetivo de desenvolver uma técnica de criação para Mahanarva fimbriolata (Stål) (Hemiptera: Cercopidae) sobre cana-de-açúcar, em laboratório $\left(25 \pm 1^{\circ} \mathrm{C}\right.$, UR de $70 \pm 10 \%$ e fotofase de 14 horas). Adultos foram isolados em gaiolas cilíndricas, com uma planta de cana-de-açúcar, contendo um disco de algodão úmido, envolto à base, como local de oviposição. Os ovos foram retirados mediante lavagem em água corrente sobre peneiras e mantidos em placas de Petri sobre papel filtro umedecido até a eclosão das ninfas. Logo após, as ninfas foram transferidas para raízes da planta e acondicionadas em caixa com tampa, para manter um ambiente úmido e escuro, favorecendo o seu desenvolvimento e a manutenção do sistema radicular, proporcionando locais de alimentação em quantidade. O método permite a produção de insetos com características semelhantes aos indivíduos selvagens e a manutenção de populações de $M$. fimbriolata em laboratório durante o ano todo, o que não ocorre na natureza, facilitando assim, o desenvolvimento de pesquisas com esse inseto.

Palavras-chave: cigarrinha-das-raízes, cana-de-açúcar
\end{abstract}

\section{INTRODUCTION}

Due to the importance of cercopids as pests in sugarcane and forage grass, studies have been conducted in order to address aspects related to the bioecology and control of these insects. In the past, the lack of suitable rearing techniques for cercopids limited the development of research on this group of insects. Rearing techniques are still scarce nowadays, eventough the first attempts were carried out in the 60's, with successful development, being constrained by low nymphal survivor (Beck, 1963). The first successful rearing technique was described by Fewkes \& Demidecki-Demidowicz (1971) for Aeneolamia varia saccharina (Distant) and Aeneolamia postica jugata (Fowler). From then on, other techniques were developed, with variations according to the objectives proposed and the species involved, such as the ones in Williams \& Cook (1975); Magalhães et al. (1987); Sotelo et al. (1988); Lapointe et al. (1989a; 1989b). 
Beck (1963); Fewkes (1964); Byers \& Wells (1966); Hagley (1967); Fewkes \& DemideckiDemidowicz (1971); King (1975); Williams \& Cook (1975); Sotelo et al. (1988); Valério (1993) have developed studies with cercopids, however their success was limited due to the technique itself or to abiotic conditions (temperature and $\mathrm{RH}$ ). At the Centro Internacional de Agricultura Tropical (CIAT), Lapointe et al. (1989a, 1989b) published a highly feasible technique that maintained Zulia colombiana and Aeneolamia reducta year-round under greenhouse conditions, and Peck et al. (2004) published a study on the most recent rearing advances, showing that this technique is one of the most effective tool for the production of spittlebugs in a large scale.

Studies involving this species are important because of the wide distribution of Mahanarva fimbriolata (Stål) (Hemiptera: Cercopidae) in Brazil and the seriousness of the damages it causes, especially in sugarcane areas harvested without the burning of the sugarcane straw. Such studies provide a better understanding about its behavior and, therefore, our objective was to develop a technique to reare this insect uninterruptedly in the laboratory, as a support to the development of new control methods.

\section{Rearing technique}

The research was carried out under laboratory conditions, with the species Mahanarva fimbriolata (Stål) for many generations, at $25 \pm 1{ }^{\circ} \mathrm{C}, 70 \pm 10 \%$ $\mathrm{RH}$, and a 14:10 hour photoperiod (photophase: scotophase). Sugarcane seedlings (variety SP 80-1842) produced in greenhouses were planted in perforated plastic containers of two sizes. The smaller $(200 \mathrm{~mL})$ were used to maintain $M$. fimbriolata adults, while the larger $(500 \mathrm{~mL})$ for nymph development. Since sugarcane is a plant that demands well aerated soil, the agricultural substrate Plantmax ${ }^{\circledR}$ Agro - Cód. Estaca was used at planting, which allowed a good root system development. The slow-release fertilizer Osmocote $^{\circledR}$ (14-14-14, NPK) (200 g / $25 \mathrm{~kg}$ of substrate) was used as a nutrient source at planting.

M. fimbriolata adults were isolated in cylindrical cages, made of transparent plastic $(60 \mathrm{~cm}$ height $\times$ $10 \mathrm{~cm}$ diameter). Each cage contained two oppositelyarranged lateral retangular openings at the upper part $(10 \mathrm{~cm}$ tall $\times 5 \mathrm{~cm}$ wide), covered with a nylon screen (approximately $1 \mathrm{~mm}$ mesh) with two wire hooks placed at opposite sides and rubber bands attached to the hooks and fastened with adhesive tape to a Petri dish $(15 \mathrm{~cm}$ in diameter) that served as the bottom of the cage, holding the cage together and to maintain the balance of the assembly (Figure 1). It was maintained at a height of $10 \mathrm{~cm}$ relative to the base of the cage.
Sexing was based on the wing patterns of the adults (Figure 2) and external examination of the genitalia (Menezes, 1982). The adults were fed on sugarcane plants (30 to 60 days of age), maintained in plastic containers $(200 \mathrm{~mL})$ under the cage. In order to obtain eggs, a Cremer ${ }^{\circledR}$ brand hydrophilic cotton disc, $6 \mathrm{~cm}$ in diameter, moistened with distilled water, was placed surrounding the base of the plant covering the entire surface area, reaching the edge of the plastic container (Figure 3). This procedure was also adopted to facilitate the daily change of the oviposition substrate, irrigation, and the eventual replacement of the plant.

Eggs were flushed from the oviposition substrate with running water over a large mesh sieve (openings of $\pm 1 \mathrm{~mm}$ ) and collected on a fine-mesh sieve immediately below (400 mesh) (Figure 4). Eggs were then transferred to Petri dishes $(6 \mathrm{~cm}$ diameter $x$ $2 \mathrm{~cm}$ height) lined with moistened filter paper until eclosion. A box made of galvanized sheet steel $(85 \mathrm{~cm}$ length $\times 40 \mathrm{~cm}$ width $\times 16 \mathrm{~cm}$ height) was used to maintain the nymphs in the laboratory and was closed with four lids $(8.5 \mathrm{~cm}$ wide $\times 85 \mathrm{~cm}$ long). Two lids on the sides were movable and were attached with hinges, while the two central lids were free. There were three spaces ( $2 \mathrm{~cm}$ wide $\times 85 \mathrm{~cm}$ long) between the central and side lids (Figure 5). Internally, the box had three supports with eight circles each $(8.5 \mathrm{~cm}$ in diameter). The supports were fixed at a height of $8 \mathrm{~cm}$ relative to the bottom of the box (Figure 6). In order to drain the excess of water from the containers there was a hole in the bottom connected to an external reservoir. Each circle of the support received a single sugarcane plant which came from the plastic container $(500 \mathrm{~mL})$ with the substrate; the plastic container was removed before the plant was placed on the support. The plant remained suspended and its secondary roots exposed (Figure 7). The box was maintained on a steelshelving unit $(1.80 \mathrm{~m}$ tall $\times 90 \mathrm{~cm}$ wide $\times 40 \mathrm{~cm}$ deep $)$. In the upper part of each space of the shelving unit there was a set of six light bulbs (two 20W daylight, two 20W Gro Lux ${ }^{\circledR}$, and two 40W incandescent), with a timer adjusted to 14 hours of light (Figure 8).

The newly hatched nymphs were transferred to the lower secondary roots of the sugarcane with a fine hair paintbrush (Figure 9), at a rate of ten nymphs per plant (240 nymphs / box). The sugarcane plants were replaced every 20 days or when they showed damage symptoms (yellowing and / or death of the leaves). Nymphs were transferred to a new plant with a ${ }^{\circ} 04$ hair paintbrush, together with some of the spittle produced by them, until the emergence of the adults.

The mean fecundity (number of eggs per female) was 342 (Garcia et al., 2006). This value is higher than those reported in literature because, accord- 

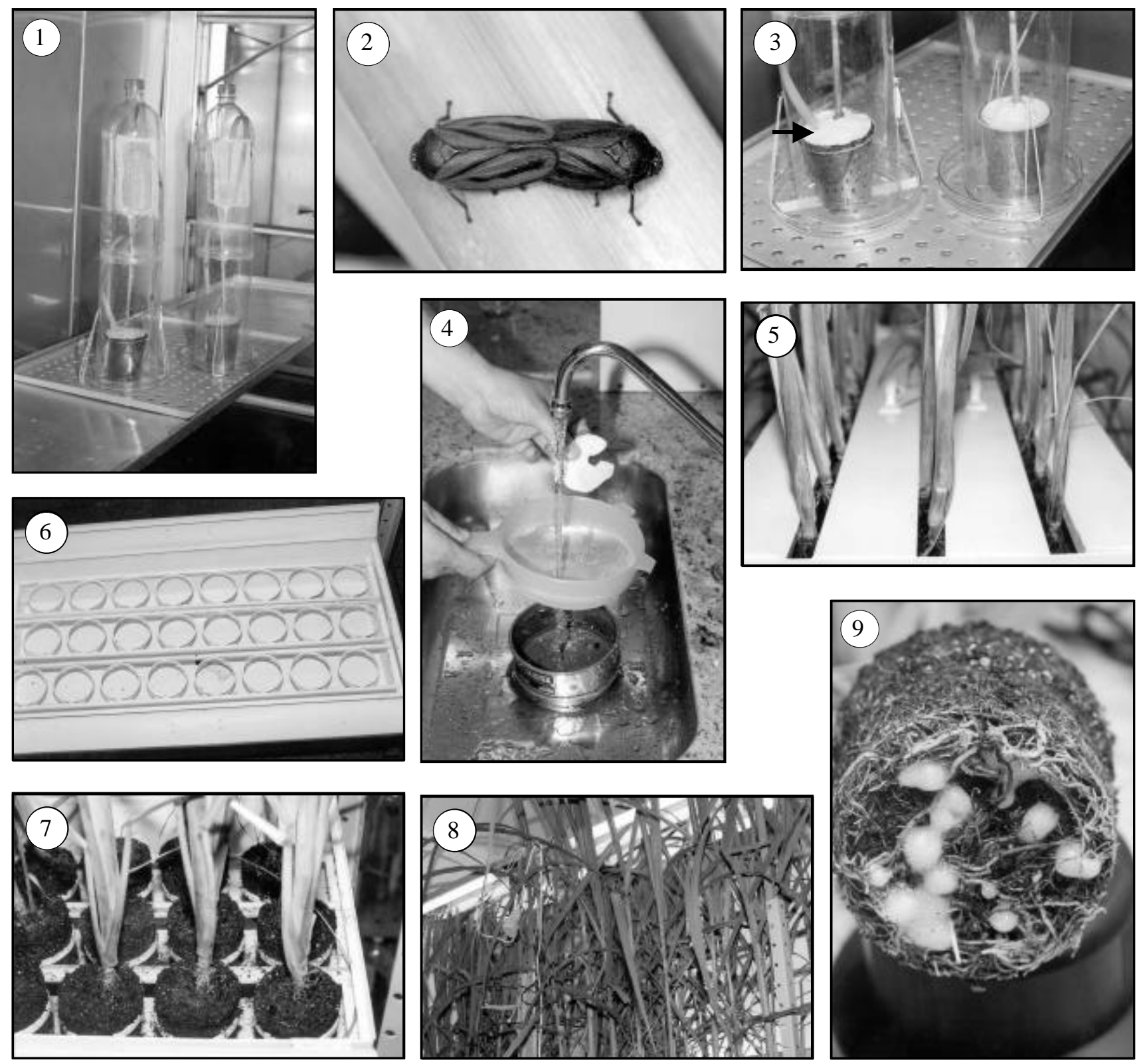

Rearing system of Mahanarva fimbriolata. Figures: (1) cylindrical plastic cage to maintain adults; (2) sexual dichromism: male (left) and female (right); (3) detail of cotton disc (indicated by the arrow) for oviposition at the base of the plant; (4) set of sieves used to separate the eggs from the cotton; (5) upper view of the box used for rearing nymphs; (6) internal view of the box, maintaining the props with suspended circles (7) detail of plants arranged in the box; (8) lighting over plants in the shelving, and (9) nymphs on sugarcane roots.

ing to Moreira (1925), females can have from 100 to 120 eggs in their ovaries. Barbosa et al. (1980) observed, on average, 146 eggs per M. fimbriolata female. Garcia et al. (2006) observed that the eggs had a high viability of $81 \%$, on average. These values evidence that both, the methodology used to obtain and remove eggs and the form by which they are maintained during the embryonic development period, are effective.

When maintained on sugarcane roots, mean nymphal survivorship was $94 \%$, demonstrating the suit- ability of the rearing system. The nymphal stage is the most problematic one, usually presenting low viability (Beck, 1963). High nymphal viability could be attributed to the use of the metallic box, which allowed the nymphs to remain covered, resulting in a moist and dark environment that is suitable for the insect as well as for both, the development and preservation of healthy sugarcane roots. The sex ratio of adults was 1:1 (1 male: 1 female). Adults with morphological, physiological, or behavioral alterations were not observed, attesting to the suitability of the developed rearing system. 
The use of the technique here described has allowed a $M$. fimbriolata colony to be maintained in laboratory for consecutive generations uninterruptedly, without contamination, and producing good quality insects. Having insects all year around facilitates basic and applied studies, since these insects will halt their development in the cooler and drier months in Brazil in natural conditions (Botelho et al., 1977).

The developed technique does not alter the characteristics of the wild insects and could be used to have insects in laboratory which were similar to those collected in the field (Garcia et al., 2006). Thus, it was possible to produce eggs, nymphs, and adults of known ages for experimental purposes year-round, which facilitates basic bioecology and management studies, including the various controlling methods for this pest.

\section{ACKNOWLEDGEMENTS}

To CAPES, for the research scholarship granted to the first author; to FAPESP, project no. 99/ 08585-9; and to Centro de Tecnologia Canavieira CTC - Piracicaba/SP, for the indispensable supply of sugarcane seedlings.

\section{REFERENCES}

BARBOSA, J.T.; RISCADO, G.M.; LIMA FILHO, M. Avanços nas pesquisas bio-ecológicas das "cigarrinhas" Mahanarva posticata Stal, Mahanarva fimbriolata Stal e Mahanarva rubicunda indentata Wlk., (Cercopidae), nos estados do Rio de Janeiro e Minas Gerais. In: ENCONTRO NACIONAL DOS ENTOMOLOGISTAS DO INSTITUTO DO AÇÚCAR E DO ÁLCOOL / PLANALSUCAR, 5., Itajaí-SC, 1980. p.116-139.

BECK, E.W. Observations on the biology and cultural-insecticidal control of Prosapia bicincta, a spittlebug, on coastal bermudagrass. Journal of Economic Entomology, v.56, p.747-752, 1963.

BOTELHO, P.S.M.; MENDES, A.C.; MACEDO, N.; SILVEIRA NETO, S. Curva populacional de Mahanarva fimbriolata em Araras - SP, e sua dependência com o balanço hídrico da região. Brasil Açucareiro, v.90, p.11-17, 1977.
BYERS, R.A.; WELLS, H.D. Phytotoxemia of coastal bermudagrass caused by the two-lined spittlebug, Prosapia bicincta (Homoptera: Cercopidae). Annals of the Entomological Society of America, v.59, p.1067-1071, 1966.

FEWKES, D.W. The fecundity and fertility of the Trinidad sugar-cane froghopper, Aeneolamia varia saccharina (Homoptera, Cercopidae). Tropical Agriculture, v.41, p.165-168, 1964.

FEWKES, D.W.; DEMIDECKI-DEMIDOWICZ, M.R. Rearing technique for sugar cane froghopper nymphs (Homoptera: Cercopidae). Annals of the Entomological Society of America, v.64, p.1471-1472, 1971.

GARCIA, J.F.; BOTELHO, P.S.M.; PARRA, J.R.P. Biology and fertility life table of Mahanarva fimbriolata (Stål) (Hemiptera: Cercopidae) in sugarcane. Scientia Agricola, v.63, p.317-320, 2006.

HAGLEY, E.A.C. Artificial diet for the adult froghopper. Nature, v.213, p.414-415, 1967.

KING, A.B.S. Factors affecting the phenology of the first brood of the sugar-cane froghopper Aeneolamia varia saccharina (Dist.) (Homoptera, Cercopidae) in Trinidad. Bulletin of Entomological Research, v.65, p.359-372, 1975.

LAPOINTE, S.L.; SOTELO, G.; ARANGO, G. Improved technique for rearing spittlebugs (Homoptera: Cercopidae). Journal of Economic Entomology, v.82, p.1764-1766, 1989a.

LAPOINTE, S.L.; SOTELO, G.; SERRANO, M.S.; ARANGO, G. Cría masiva de especies de cercópidos en invernadero. Pasturas Tropicales, v.11, p.25-28, 1989b.

MAGALHÃES, B.P.; PARRA, J.R.P.; SILVA, A.B. Técnica de criação e biologia de Deois incompleta em Brachiaria. Pesquisa Agropecuária Brasileira, v.22, p.137-144, 1987.

MENEZES, M. As cigarrinhas-das-pastagens (Homóptera: Cercopidae) na região sul da Bahia, Brasil: Identificação, distribuição geográfica e plantas hospedeiras. Boletim Técnico CEPLAC, v.104, p.1-48, 1982.

MOREIRA, C. A cigarrinha vermelha da cana de assucar (Tomaspis liturata Lep. \& Serv.). Boletim do Instituto Biológico de Defesa Agrícola, v.4, p.1-23, 1925.

PECK, D.C.; MORALES, A.; CASTRO, U. Alternative Methods for Rearing Grass-Feeding Spittlebugs (Hemiptera: Cercopidae). Neotropical Entomology, v.33, p.307-314, 2004.

SOTELO, G.; LAPOINTE, S.L.; ARANGO, G.L. Nueva tecnica de cria del "salivazo de los pastos" en invernadero (Homoptera: Cercopidae). Revista Colombiana de Entomología, v.14, p.3-6, 1988.

VALÉRIO, J.R. Obtenção de ovos de cigarrinhas (Homoptera: Cercopidae) em agar-água. Anais da Sociedade Entomológica do Brasil, v.22, p.583-590, 1993.

WILLIAMS, J.M.; COOK, J.M. Technique for rearing the twolined spittlebug. Journal of Economic Entomology, v.68, p.421-422, 1975.

Received May 29, 2006

Accepted January 16, 2007 
This article has received corrections in agreement with the ERRATUM published in Volume 64 Number 2. 